\title{
血液透析患者の下大静脈径変化に対する心囊液貯留の影響
}

\author{
大野修一安藤康宏手塚俊文增永義則 \\ 浅 野 泰 \\ 自治医科大学腎臓内科
}

key words : inferior vena cava, hemodialysis, pericardial effusion, ultrasonography, dry weight

〈要旨〉

下大静脈 (IVC) 径は循環血液量や中心静脈圧, 血中心房性ナトリウム利尿ペプチド濃度と相関し, 透析患者の体液 量の指標として有用である。しかし, 心囊液 (PE) 貯留のある患者では, 静脈還流が阻害され血液透析 (HD) 中のIVC 径の動態が通常の HD 患者と異なることが予想される。 そこで, 今回, PE 貯留が除水によるIVC 径変化にどのよう に影響するかを検討した。適正な dry weight が維持された PE を認めない安定維持期症例では, HD 終了時に安静呼 気時最大径 (IVCe, mean $\pm S E$ ) は 7.2 $\pm 0.2 \mathrm{~mm}$, 安静吸気時最小径 (IVCi) は $0.1 \pm 0.1 \mathrm{~mm}$ となり, 吸気時のIVC の 虚脱度 (collapsibility index, Cl : 1-IVCi/IVCe) は 0.99 00.01 となるのに対し, PE 貯留の程度が強くなるほど, HD 終了時の IVCe, IVCi は高値になり, Cl は小さくなる傾向がみられた。特に心タンポナーデ前段階の大量 PE 貯留症 例では, 除水で体液量が減少し血圧低下をきたしても, IVCe は $20 \mathrm{~mm}$ 以上に拡張したまま減少せず, 吸気時のIVC の虚脱もほとんど認めなかった。 以上よりPE 貯留時は, 静脈還流が阻害され, 除水しても IVC 径が減少せず, IVC 径と体液量の相関が失われると考えられた. よって, IVC 径を HD 患者の体液量の指標とする際, PE 貯留の有無を あらかじめ検討する必要があると思われた。

\section{Inferior vena caval diameter in hemodialysis patients with pericardial effu- sion}

Shuichi Ono, Yasuhiro Ando, Toshifumi Tetsuka, Yoshinori Masunaga, Yasushi Asano

Department of Internal Medicine, Division of Nephrology, Jichi Medical School

The ultrasonographically determined diameter of the inferior vena cava (IVC) correlates with circulating blood volume, central venous pressure and plasma atrial natriuretic peptide level. Therefore, IVC is a good parameter of body fluid volume in hemodialysis (HD) patients. Since right-side cardiac overload could alter this correlation, we studied IVC diameter during HD in a uremic patient with pericardial effusion (PE). In stable chronic HD patients without $\mathrm{PE}$, the mean maximal IVC diameter during quiet expiration (IVCe) and the minimal diameter during quiet inspiration (IVCi) decreased in parallel with the removal of body fluid during $\mathrm{HD}$ and became $7.2 \pm 0.2 \mathrm{~mm}$ and $0.1 \pm 0.1 \mathrm{~mm}$, respectively, at the end of HD (mean \pm SE). On the other hand, as the amount of PE increased, IVCe and IVCi were greater at the end of HD. In three patients with massive PE, IVCe was more than $20 \mathrm{~mm}$ and did not change even with the induction of hypovolemic hypotension by water removal. These results suggest that IVCe does not correlate with the amount of body fuid in the presence of massive PE. We conclude that the degree of $\mathrm{PE}$ should be examined in measuring IVC diameter as a marker of body fluid volume in HD patients.

\section{緒言}

下大静脈 (IVC) 径とその呼吸性変動 Collapsibility Index (CI) は循環血液量 (CBV) や中心静脈圧 (CVP)
のない血液透析 (HD) 患者で, 除水とともに安静呼気時 最大径 (IVCe) および安静吸気時最小径 (IVCi) が減少 し，CI が増加することを報告した ${ }^{4,5)}$ 。また，右心負荷を 有する心房中隔欠損症 (ASD) 症例でも除水による IVC 
径変化の基本的パターン，即ち, IVCe, IVCi の減少, CI の増加は保たれたが, 圧負荷も除水によるIVC 径減少を 修飾する因子であることを報告しだ、

透析患者には心囊液 (PE) 貯留がしばしば見られる が, PEを有する患者においては, 心囊内圧の上昇のため 静脈還流が阻害され HD 中の IVC 径の動態が通常の $\mathrm{HD}$ 患者と異なることが予想される。そこで, 今回, $\mathrm{PE}$ 貯留が除水によるIVC 径変化にどのように影響するか を検討した。

\section{対象と方法}

\section{1. 対象}

心肺疾患のない $\mathrm{HD}$ 患者 5 名 (男 1 名，女 4 名，年齢 $46 \pm 3$ 歳, $\mathrm{HD}$ 期間 $40 \pm 19$ 名月), $\mathrm{PE}$ を有する HD 患 者 12 名 (男 5 名, 女 7 名, 年齢 $59 \pm 4$ 歳, HD 期間 $10 \pm$ 6 加)。

2. 方法

1) IVC 内径の測定

超音波断層装置 (SSA650CL, Aloka) を用い図 1 のご とく仰臥位にて, 剣状突起下で IVC 矢状断を描出し, IVCe, IVCi を計測した ${ }^{4 \sim 7}$. 両内径の計測点は肝静脈合 流部より遠位で, 安静吸気時に径が最小となる部位とし

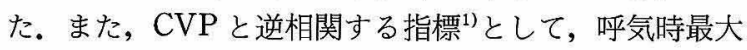
径に対する吸気時の径の減少率すなわち collapsibility index (CI) を次の式から算出した。CI は CVP と逆相 関することが知られている ${ }^{1,2)}$.

$$
\mathrm{CI}=(\mathrm{IVCe}-\mathrm{IVCi}) / \mathrm{IVCe}
$$

計測は HD 開始前〜終了直後まで 15〜30 分間隔で, ベッド上仰臥位の状態にて行った。大量の PE 貯留があ る症例では HD 中のみならず, PE 吸引前後の IVC 径 も測定した。

対照群， $\mathrm{PE}$ 群とも透析液には $\mathrm{AK}$ ーソリタ® を用い, 血流量は $180 \sim 200 \mathrm{~m} l / \mathrm{min}$ (前腕部内シャント), 透析液 流量は $500 \mathrm{~m} l / \mathrm{min}$, 透析時間は 4 時間，ダイアライザー はキュプロファン膜, 一部の症例では PAN 膜を用い HDを行った。

2) 血圧, 脈拍, 体重 (BW), 除水量

血圧，および脈拍数をIVC の計測と同時に記録した。 BW の測定は透析前後に行い, 透析中の值は食事量, 飲 水量, 輸液量, 除水量より算出した。除水量は自動除水 量設定のできる透析装置を用いて測定した。

3 ) 循環血液量 (CBV)

CBV は HD 開始直前に ${ }^{131} \mathrm{I}-$ albumin 希釈法 (Volumétron) により求め $\left(\mathrm{CBV}_{\mathrm{pre}}\right)$, さらに $\mathrm{HD}$ 中の $\mathrm{CBV}\left(\mathrm{CBV}_{\mathrm{t}}\right)$ を $\mathrm{HD}$ 前, および $\mathrm{HD}$ 中 IVC 計測時点ご とに測定したシャント血へマトクリット值（各々 $\mathrm{Ht}_{\mathrm{pre}}$,

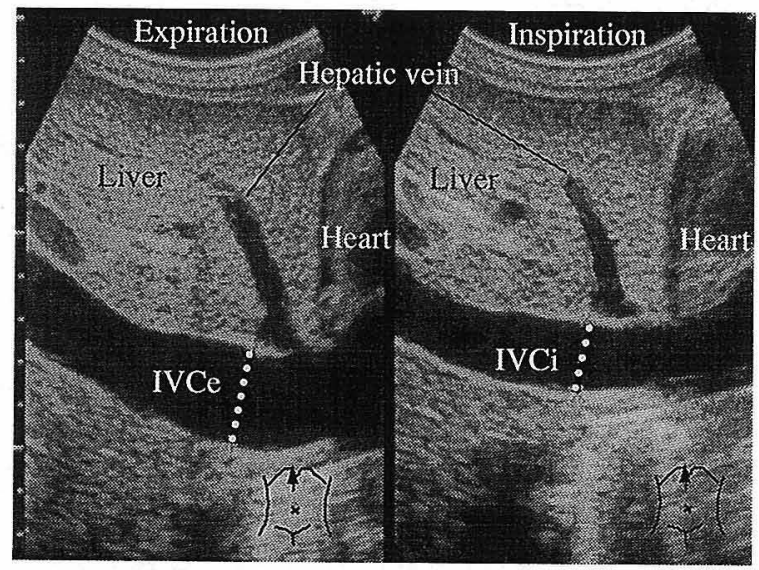

図 1 Measurement of the IVC diameters. The maximal diameter of IVC at distal of hepatic vein junction in quiet expiration (IVCe, left) and the minimal diameter in quiet inspiration (IVCi, right) were measured. Collapsibility index (CI) was calculated as: $\mathrm{CI}=(\mathrm{IVCe}$ -IVCi)/IVCe.

$\mathrm{Ht}_{\mathrm{t}}$ ) から次のごとく求めた.

$$
\mathrm{CBV}_{\mathrm{t}}=\mathrm{CBV}_{\text {pre }} \times \mathrm{Ht}_{\mathrm{pre}} / \mathrm{Ht}_{\mathrm{t}}
$$

\section{4) PE 貯留程度の分類}

図 2 に示すように心臓の長軸断面を描出し M-mode 像により, Yoshida らの分類 ${ }^{8}$ にしたがって, PE 貯留の 程度を評価した.すなわち, PE 貯留の認められないもの を grade 0 , 後壁に収縮期のみ $5 \mathrm{~mm}$ 以下の貯留が認め られるものを grade I, 収縮期にのみ認められ, $5 \mathrm{~mm}$ 以 上の貯留があるものを grade II, 後壁に収縮期のみなら ず拡張期にも認められるものを grade III, 後壁のみなら ず前壁にも認められるものを grade IV，後壁，前壁とも に大量に認められるものを grade Vとした。

\section{結果}

$\mathrm{PE}$ を認めない症例の HD の除水に伴う IVC 径の変 化：典型的には図 3 , 下に示すように, 透析中の除水に より体重の低下とともに CBV が減少した。同時に図 3， 上に示すように IVCe, IVCi は減少し, CI は増加した。 $\mathrm{HD}$ 終了時には, IVCe (mean $\pm \mathrm{SE})$ は $7.2 \pm 0.2 \mathrm{~mm}$, IVCi は $0.1 \pm 0.1 \mathrm{~mm}$ となり, CI は $0.99 \pm 0.01$ となっ た.

大量 $\mathrm{PE}$ 貯留を認める $\mathrm{HD}$ 患者の $\mathrm{PE}$ 吸引前後の除水 による IVC の変化：図 4 に grade Vの大量 PE 貯留を 認めた HD 患者 2 例の, 除水中の IVCe と血圧の変化を 示した. 両症例とも大量 $\mathrm{PE}$ 貯留時は $\mathrm{HD}$ 中の除水によ り血圧は低下しても IVCe は $20 \mathrm{~mm}$ 以上に拡張したま ま減少しなかった。これに対し，PEをそれぞれ $1.3 \mathrm{~L}$ お お 
long-axis echocardiogram

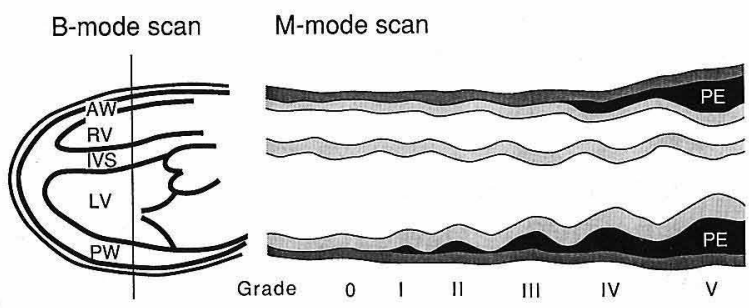

図 2 Grading of pericardial effusion based on long-axis echocardiographic findings ${ }^{8}$. Grade 0 : No effusion., Grade I : Pericardial effusion is present only in systole., Grade II : The width of the echo-free space between peri- and epicardium is more than $5 \mathrm{~mm}$., Grade III : Echo-free space is present in both systole and diastole., Grade IV : Effusion is present in both anterior and posterior pericardial space., Grade V: Massive effusion. $\mathrm{AW}=$ anterior wall ; $\mathrm{RV}=$ right ventri cle ; IVS = interventricular septum ; $\mathrm{LV}=$ left ventricle; $\mathrm{PW}=$ posterior wall ; $\mathrm{PE}=$ pericardial effusion.

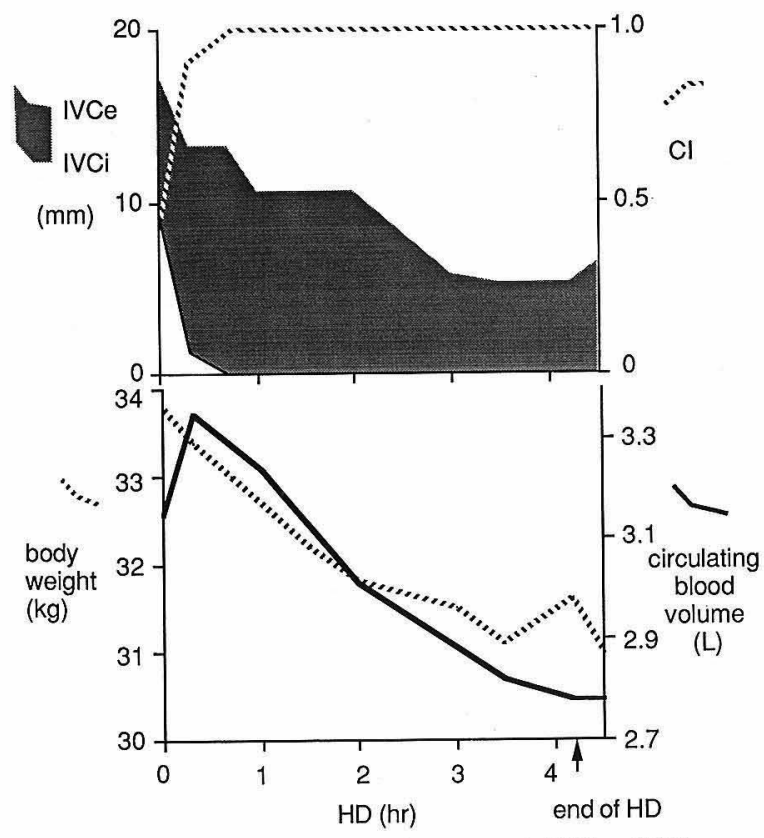

図 3 Representative changes of IVCe, IVCi, $\mathrm{CI}$, body weight and CBV by the removal of body fluid during $\mathrm{HD}$ in a patient without cardiopulmonary disease. During $\mathrm{HD}$, both IVCe and IVCi were decreased while the $\mathrm{CI}$ increased by the removal of body fluid. At the end of $\mathrm{HD}$, IVCe became less than $10 \mathrm{~mm}$ and IVCi was $0 \mathrm{~mm}$.
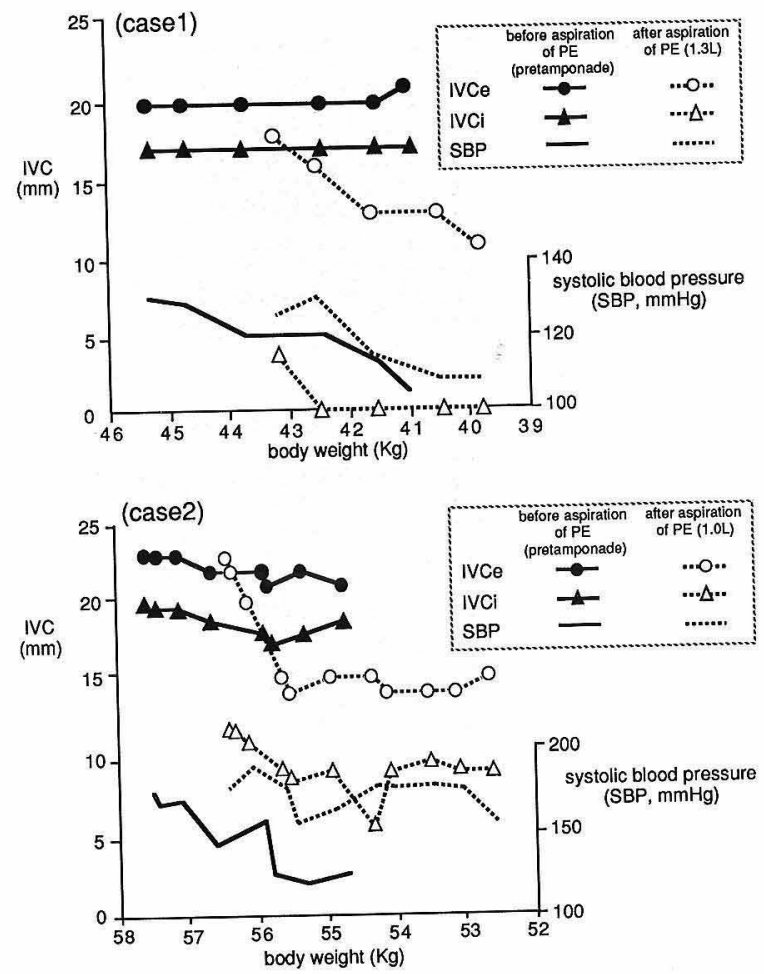

図 4 Changes of IVCe and systolic blood pressure induced by the removal of body fluid during $\mathrm{HD}$ before and after aspiration of $\mathrm{PE}$ in two patients with massive PE. In these patients, IVCe was more than $20 \mathrm{~mm}$ and remained unchanged despite of induction of hypovolemic hypotension by water removal. After aspiration of $\mathrm{PE}$ (1.3 and $1.0 \mathrm{~L}$ in case 1 and 2 , respectively), IVCe decreased in response to the removal of body fluid.

よび $1.0 \mathrm{~L}$ 吸引後には同じ体重でも IVCe の值は PE 吸 引前に比べ小さく, HD 中の除水により IVCe の減少を 認めるようになった。

$\mathrm{PE}$ の IVC 径に対する影響：図 5 は grade VのPE 貯 留のあった症例に対し, 非 $\mathrm{HD}$ 時に行った $\mathrm{PE}$ 吸引直前 直後の IVC の M-mode 像である. PE 吸引前の IVC (図 5 ，上)は拡張したまま吸気時にも虚脱せず，また CI の值はほぼ0であった（すなわち frozen IVC)。一方, 図 5, 下の M-mode 像のように, $\mathrm{PE}$ 吸引後は呼吸性変 動が明らかで，CI 值は増加した。同様の測定を行った， 本例を含む grade $\mathrm{V}$ の 3 症例の $\mathrm{PE}$ 吸引前後の $\mathrm{CI}$ 值の 変化を図 6 にまとめた。 3 例とも $\mathrm{PE}$ を吸引することで grade がVからIVとなり, CI が増加し, これは吸引に よって CVP が減少したことを表している1,2).

$\mathrm{PE}$ の grade 別透析終了時の IVC と CI : 図 7 に $\mathrm{PE}$ 


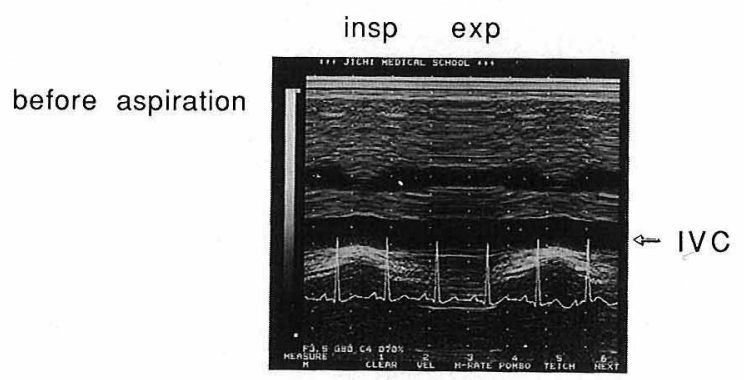

after aspiration of pericardial effusion $(1300 \mathrm{ml})$

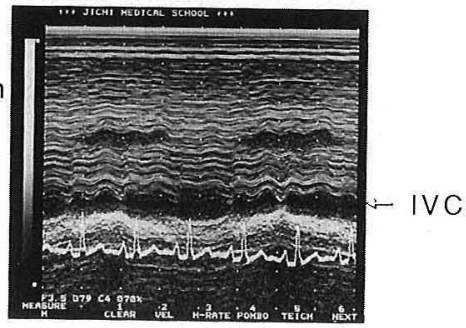

图 5 M-mode ultrasonography of IVC before and after aspiration of $\mathrm{PE}$ in a patient with massive PE. Before aspiration, the IVC diameter did not change by respiration (frozen IVC), whereas the respiratory change of IVC was evident after the aspiration.

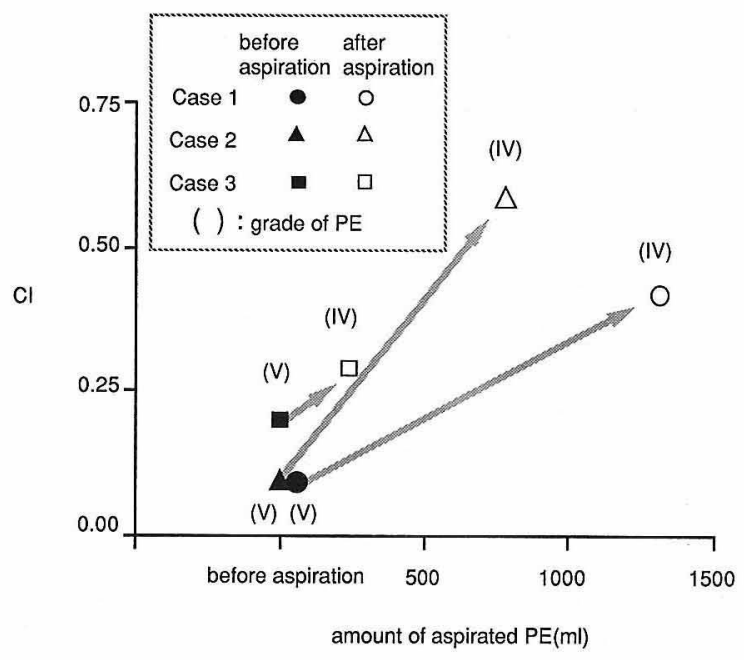

图 6 Changes in CI during aspiration of $\mathrm{PE}$ in three patients with massive PE. In all cases, aspiration of $\mathrm{PE}$ resultes in an increase in $\mathrm{CI}$.

の grade と $\mathrm{HD}$ 終了時の IVCe, IVCi (図 7, 上), CI (図 7, 下) の関係を示す.PE貯留の程度が強くなるほ ど, 血圧維持限界までの除水を行っているにもかかわら ず，HD 終了時の IVCe, IVCi は高值に，CI は低值にな り，grade Vでは前述のようにIVCはほぼ拡張したまま となった。このような IVC 径の虚脱制限は, grade III, 即ち左室後壁の心囊液が拡張期にも見られる段階で起こ り始めた。

考察

IVC は high compliance vessel ${ }^{9)}$ であり, CVP の変 化は鋭敏に IVC 径に反映される ${ }^{2,3,6)}$. 我々は HD 患者 の IVC 径を検討し, HD 中除水とともに IVCe, IVCi が 減少し, CI が増加すること, IVCe が, CBV あるいは 血中心房性ナトリウム利尿ペプチド濃度と有意に相関す ること ${ }^{4,5,10)}$ ，また ASD を合併した HD 患者の手術前後 の IVC 径の検討から, 容量のみならず圧も IVC 径を規 定している事を報告した に，この数年，我々の施設では実際の診療の場において も体液量の推定, HD 中の除水量の設定の際などに日常 的検查として IVC 径測定を行っている。しかしながら， HD 患者には PE 貯留がしばしばみられ によっては静脈還流を阻害するため, IVC 径と体液量, $\mathrm{CBV}$ との相関関係が異なってくることが予想される。そ こで今回, PE 貯留の IVC 径に対する影響を調べ, PE 貯留症例においても IVC 径が体液量の指標となるか否 かを検討した。

心肺合併症のない症例では, $\mathrm{HD}$ 中の除水による $\mathrm{BW}$ の減少, CBV の減少とともに, IVCe は $10 \mathrm{~mm}$ 以下に 減少し，CI はほぼ 1.0 まで増加した(図 3，7)。PE が 心臓前後壁ともに大量に認められる2症例では, 除水で 血圧は低下しても IVCe は $20 \mathrm{~mm}$ 以上, CI も 0.2 以下 のまま殆ど変化しなかったが，PE を各々 $1.3 \mathrm{~L}$ ，および $1.0 \mathrm{~L}$ 吸引後の HD では除水による IVCe の減少, CI の 増加が認められた (図 4).大量 PE 貯留の 3 症例で, 非 $\mathrm{HD}$ 時に行った PE 吸引前後の IVC 径計測では, 3 例 とも $\mathrm{PE}$ 吸引のみで CI が改善した（図 6 ).

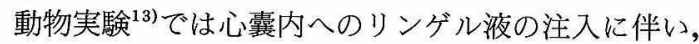
心囊内圧は徐々に上昇し動脈圧は減少，CVP は上昇す る. CVP は CI と負の, IVCe と正の相関関係があり ${ }^{2,3,6)}$, $\mathrm{PE}$ 貯留患者では, $\mathrm{PE}$ 貯留に伴い心囊内圧が上昇するこ とによって, 右室内圧が上昇し ${ }^{14)}$ 静脈還流が阻害され, CVP が上昇するため IVC 径の動態が通常の HD 患者と 異なってくるものと考えられた。大量 PE 貯留時は IVC 径と体液量の相関が失われていることが明らかであるが (図 4), HD 終了時の IVCe, CI と PE 量の関係を見る と,IVC 径に対する影響は PE が大量貯留に到る以前に, grade III前後ですでに現われることが示唆された（図 7).これは, 心タンポナーデが "all-or-none" 現象では ない(14,15)ことを裹付けていると思われた。

心囊液が急性に貯留した場合と, 徐々に貯留した場合 

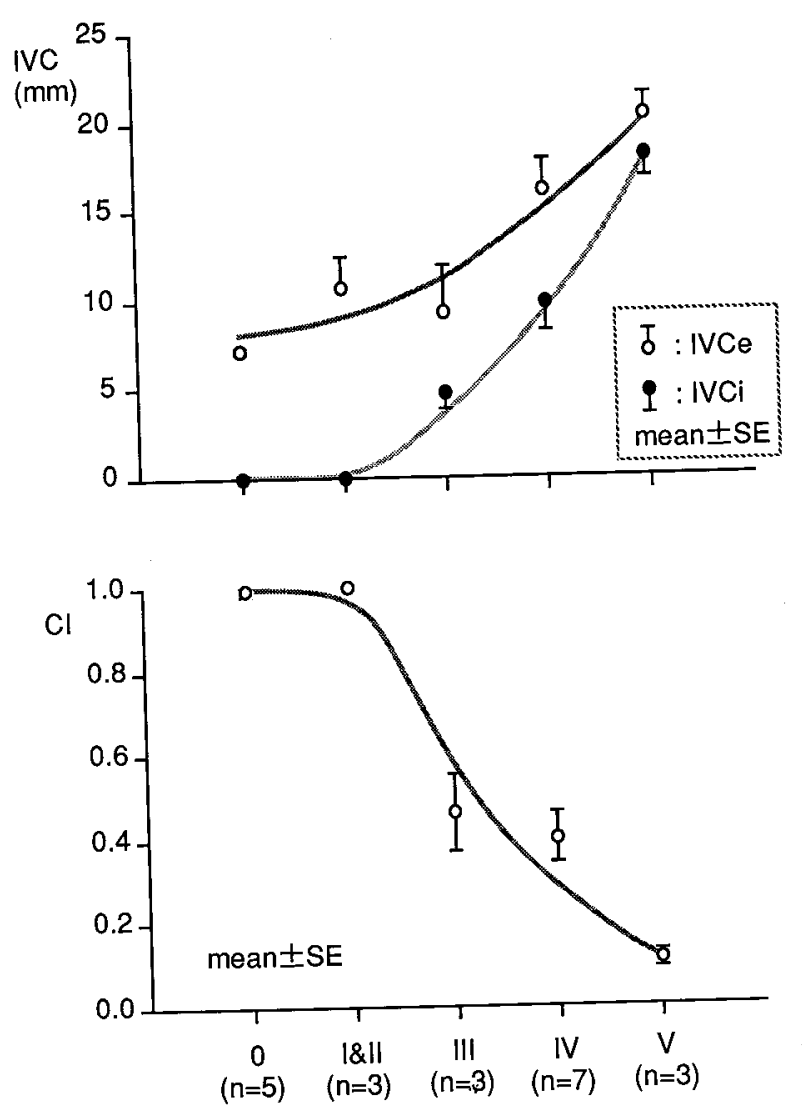

Grading of PE

図 7 Relationship between IVCe, CI and the grade of $\mathrm{PE}$ at the end of $\mathrm{HD}$. In patients with PE, IVCe and IVCi at the end of HD became greater as the amount of $\mathrm{PE}$ increased.

とでは, 同じ gradeでも静脈還流に及ぼす影響にも違い があると思われるが，この点については今回の検討では 例数が少ないため結論が出せなかった. 今後検討を要す る点と考えている。

いずれにせよ，IVC 径を HD 患者の体液量の指標と する際，あらかじめ PE 貯留の程度を検討をするべきで あり, 特に大量 PE 貯留時は IVC 径は体液量, 除水量 の指標とはならないことに留意する必要がある。

\section{結論}

1) 大量 PE 貯留時は, 静脈還流が阻害され, 除水し ても IVC 径が減少せず, IVC 径と体液量の相関が失わ れると考えられた。

2 ) このような PE の影響は grade Vでは明らかだ が, それ以前に grade III, 即ち左室後壁のPE が搪張期 にも見られる段階ですでに現われることが示唆された。
3) IVC 径を $\mathrm{HD}$ 患者の体液量の指標とする際, grade III以上の PE 貯留の有無を考慮する必要があると 思われた。

本論文の要旨は第 36 回日本透析療法学会において発表し た.

\section{文献}

1）玉城 繁：下大静脈の前後径の呼吸性変動と中心静 脈圧。日胸疾会誌 $19: 460-469 ， 1981$

2）椎名 明：心エコー図による右心機能評価. 医学の あゆみ $131 ： \mathrm{E}-223-\mathrm{E}-237,1984$

3）酒井泰彦，菱田 仁，坂部慶幸，宮城 裕，野村雅 則, 水野 康:下大静脈エコーと静脈還流および中 心静脈圧の関係の検討。超音波医学 $10: 258-261$, 1983

4）安藤康宏，田部井薰，椎名 明，浅野 泰，細田瑳 一：超音波断層法による血液透析中の下大静脈内径 変化の検討一特に除水量との関係について一. 透析 会誌 $18 ： 173-179,1985$

5）安藤康宏：血液透析患者の下大静脈エコーーdry weight 設定の一指標として一。医学のあゆみ 154 ： 118, 1990

6）大野修一, 安藤康宏, 手塚俊文, 江幡 理, 浅野 泰 : 心房中隔欠損症を伴った血液透析患者の下大静脈径 の検討. 透析会誌 $26: 351-357,1993$

7）増永義則, 安藤康宏, 大野修一, 手塚俊文, 浅野 泰: CAPD 患者の下大静脈径の検討. 透析会誌 25 ： 1337-1342, 1992

8) Yoshida K, Shiina A, Asano Y, Hosoda S : Uremic pericardial effusion : detection and evaluation of uremic pericardial effusion by echocardiography. Clin Nephrol $13: 260-268,1980$

9) Guyton AC, Armstrong GG, Chipley PL: Pressure-volume curves of the arterial and venous systems in live dogs. Am J Physiol 184 : 253-258, 1956

10）赤井洋一, 草野英二, 古谷裕章, 大野修一, 江幡 理, 手塚俊文, 安藤康宏, 鈴木宗弥, 田部井薰, 浅野泰: 透析患者の ANP は体液貯留の指標となりうる か? . 透析会誌 $24: 1143-1148,1991$

11) Renfrew R, Buselmeier TJ, Kjellstrand CM : Pericarditis and renal failure. Ann Rev Med $31: 345$ $-360,1980$

12) Luft FC, Gilman JK, Weyman AE : Pericarditis in the patient with uremia : clinical and echocardio- 
graphic evaluation. Nephron 25 : 160-166, 1980

13）佐藤正明, 前田 肇, 酒井 章, 大島宣雄: 心不全 モデルにおける微小循環動態一生態顕微鏡による観 察一. 脈管学 $26: 157-160,1986$

14) Reddy PS, Curtiss EI, Uretsky BF : Spectrum of hemodynamic changes in cardiac tamponade. Am J Cardiol 66 : 1487-1491, 1990

15) Reddy PS, Curtiss EI, O’Toole JD, Shaver JA : Cardiac tamponade: hemodynamic observations in man. Circulation $58: 265-272,1978$ 